Acta Universitatis Wratislaviensis • No 3869

Literatura i Kultura Popularna XXIV, Wrocław 2018

DOI: $10.19195 / 0867-7441.24 .19$

\title{
Robert Dudziński
}

ORCID: 0000-0002-8387-4314

Uniwersytet Wrocławski

\section{Agent 007 za żelazną kurtyną. \\ Fenomen Jamesa Bonda w piśmiennictwie kulturalnym Polski Ludowej}

\author{
Słowa kluczowe: James Bond, historia recepcji, kultura popularna, Polska Ludowa, Polska \\ Rzeczpospolita Ludowa
}

Keywords: James Bond, history of reception, popular culture, Polish People's Republic

W opublikowanym w 2014 roku na łamach „Kwartalnika Filmowego” artykule Metodologiczne problemy badania kina PRL-u Piotr Zwierzchowski i Krzysztof Kornacki starali się naszkicować mapę obszarów badawczych domagających się gruntownego opracowania $\mathrm{w}$ ramach szeroko pojętej historii rodzimej kultury filmowej. Pośród różnych potencjalnych przedmiotów analizy wymienianych przez autorów pracy znalazło się miejsce także na recepcję filmów i polskie piśmiennictwo filmowe ${ }^{1}$. Według Zwierzchowskiego i Kornackiego opisanie tego terytorium to jeden z kroków niezbędnych do odtworzenia pełnego kontekstu, w którym funkcjonowało w Polsce rodzime i zagraniczne kino. O tym, że badania nad odbiorem i nad dyskursem okołofilmowym mogą przynosić interesujące poznawczo rezultaty wzbogacające naszą wiedzę o kulturze filmowej PRL-u, dobitnie świadczą przeprowadzone z tej perspektywy analizy autorstwa

${ }^{1}$ P. Zwierzchowski, K. Kornacki, Metodologiczne problemy badania kina PRL-u, ,Kwartalnik Filmowy" 2014, nr 85, s. 37-38. 
Kornackiego $^{2}$ i Zwierzchowskiego ${ }^{3}$, a także Moniki Talarczyk-Gubały ${ }^{4}$, Barbary Klich-Kluczewskiej ${ }^{5}$, Patryka Wasiaka ${ }^{6}$, Grzegorza Fortuny ${ }^{7}$ i wielu innych ${ }^{8}$. Każdy z wymienionych badaczy przyglądał się innym okresom historycznym i w odmienny sposób wyznaczał zakres problemowy swoich studiów, przywoływane teksty łączy jednak trafne zrekonstruowanie kodów odbiorczych strukturyzujących rodzimy dyskurs krytycznofilmowy.

Wszystkie wymienione studia stały się inspiracją dla niniejszego tekstu, który również ma stanowić punktowe spojrzenie na wycinek dyskursu filmowego i kulturalnego Polski Ludowej. Przedmiotem mojego zainteresowania były rodzime świadectwa odbioru fenomenu Jamesa Bonda. Mimo że przeciętny polski czytelnik i widz aż do lat 80 . XX wieku nie mógł poznać przygód tego bohatera bezpośrednio (ani w formie literackiej, ani filmowej), skala popularności tej marki na Zachodzie sprawiła, że echa tak zwanej bondomanii zaczęły docierać również za żelazną kurtynę. Polscy krytycy i publicyści próbowali przybliżyć swojemu czytelnikowi ten fenomen i wyjaśnić go, sięgając po najrozmaitsze kategorie interpretacyjne. Właśnie te próby zrozumienia i ocenienia fenomenu Bonda będą mnie tutaj bezpośrednio interesować ${ }^{\text {. }}$.

Można wskazać trzy zasadnicze powody, dla których temat ten wydaje się warty analizy. Po pierwsze, motywy bondowskie - mimo nieobecności oryginału - funkcjonowały w rozmaitych tekstach kultury powstających w Polsce Ludowej, w części z nich stanowiąc wręcz element kluczowy. W Historii nieby-

${ }^{2}$ K. Kornacki, ,Popiót i diament” Andrzeja Wajdy, Gdańsk 2011, rozdz. Krytyka o filmie.

${ }^{3}$ P. Zwierzchowski, Recepcja kinematografii niemieckich $w$ piśmiennictwie filmowym 19451956, [w:] idem, Pęknięty monolit. Konteksty polskiego kina socrealistycznego, Bydgoszcz 2005; idem, Portret wroga w piśmiennictwie filmowym pierwszej połowy lat 50., [w:] idem, Pęknięty monolit...

${ }^{4}$ M. Talarczyk-Gubała, Poszukiwana, poszukiwany... Krytyka wobec polskiej komedii filmowej lat 1945-1989, [w:] Polskie kino popularne, red. P. Zwierzchowski, D. Mazur, Bydgoszcz 2011.

${ }^{5}$ B. Klich-Kluczewska, Młodzież, seks, cenzorzy i ludzie. Debata wokół filmu ,Seksolatki”, [w:] Kultura popularna w Polsce 1944-1989. Między projektem ideologicznym a kontestacja, red. K. Stańczak-Wiślicz, Warszawa 2015.

${ }^{6}$ P. Wasiak, „Zwoje muskułów monstrualnych rozmiarów i dużo nagiego ciała”. Kultura popularna, nowe technologie medialne i legitymizacja socjalistycznego projektu kulturowego, „Kultura Popularna" 2014, nr 40, https://kulturapopularna-online.pl/resources/html/article/details?id=12283 (dostęp: 23.10.2016); idem, Filmy akcji, magnetowidy i autorytet krytyków kulturalnych, [w:] Kultura popularna $w$ Polsce...

${ }^{7}$ G. Fortuna jr, King Bruce Lee karate mistrz. Recepcja filmów sztuk walki w PRL-u, [w:] Poszukiwacze zaginionych znaczeń. Perspektywa (wy)twórcy, odbiorcy i krytyka w badaniach nad kultura audiowizualna, red. K. Łuczyńska, M. Stańczyk, Kraków 2016.

${ }^{8}$ Zob. zwł. studia zebrane w tomie Polskie piśmiennictwo filmowe (red. P. Zwierzchowski, B. Giza, Bydgoszcz 2013).

${ }^{9}$ Bezpośrednich metodologicznych inspiracji do badań nad historią odbioru dostarczyły mi propozycje J. Staiger (W stronę historyczno-materialistycznych badań nad recepcja filmu, przeł. I. Kurz, [w:] Film i historia. Antologia, red. I. Kurz, Warszawa 2008) oraz M. Głowińskiego (Style odbioru. Szkice o komunikacji literackiej, Kraków 1977). 
tej kina PRL Tadeusz Lubelski omawia między innymi niezrealizowany projekt filmu Nasz człowiek w Warszawie, do którego scenariusz w 1967 roku napisali Stanisław Bareja i Jacek Fedorowicz. Według krakowskiego filmoznawcy istniejące projekty scenariusza pozwalają traktować ten film jako parodię cyklu bondowskiego $^{10}$. Prowokuje to rzecz jasna pytanie, stawiane również przez Lubelskiego, o stan filmowej świadomości rodzimych odbiorców mogących mieć tylko zapośredniczoną wiedzę o przygodach agenta brytyjskiego wywiadu. Dla takich projektów jak Nasz człowiek w Warszawie rekonstrukcja dyskursywnego obrazu fenomenu Jamesa Bonda w Polsce Ludowej jest więc kluczowa.

Po drugie, należy zaznaczyć, że analiza wypowiedzi krytycznych poświęconych Bondowi pozwala spojrzeć na rodzimą kulturę filmową w perspektywie transnarodowej. Polski dyskurs o brytyjskich filmach był bowiem (pośrednio i bezpośrednio) współtworzony i modelowany także przez wypowiedzi krytyków francuskich $^{11}$, radzieckich ${ }^{12}$ czy niemieckich $^{13}$, co więcej, bardzo często przy okazji omawiania popularności cyklu o Bondzie publicyści przywoływali włoskie czy amerykańskie produkcje naśladujące formułę kina szpiegowskiego spod znaku agenta 007. Teksty poświęcone serii bondowskiej pozwalają więc prześledzić, jak w rodzimym piśmiennictwie filmowym spotykały się różne kultury i jak sposoby pisania o nich były uwarunkowane lokalnym kontekstem.

Po trzecie wreszcie, ślady polskiej recepcji Jamesa Bonda — bohatera ikonicznego - można potraktować jako swoistą próbkę PRL-owskiego dyskursu poświęconego globalnej kulturze popularnej. Wielopostaciowy i wieloletni fenomen brytyjskiego agenta pozwala na prześledzenie, jak w kolejnych latach zmieniały się zarówno kody interpretacyjne używane do opisu zjawisk kultury masowej, jak i sposób konceptualizacji tej kultury. Specyfika bondowskiego fenomenu sprawiła, że poświęcone mu teksty powstawały w ciągu kilkudziesięciu lat, przechowując typowe dla danego okresu przekonania i wyobrażenia o kulturze popularnej.

Mając na uwadze te trzy zasadnicze kwestie, starałem się zrekonstruować i usystematyzować style odbioru uruchamiane w piśmiennictwie Polski Ludowej w kontekście cyklu o Bondzie. Analizowane przeze mnie teksty pochodzą zarówno z publikacji zwartych, jak i z czasopism o bardzo różnym charakterze (od „Kina”, przez „Kulturę” i „Odgłosy”, po „Trybunę Ludu”). Zebrany materiał badawczy z pewnością nie jest jeszcze kompletny, stanowi jednak reprezenta-

10 T. Lubelski, Historia niebyła kina PRL, Kraków 2012, s. 161-173. Dzieje tego projektu analizuje również A. Wyżyński (Niezrealizowane pomysty filmowe Stanisława Barei, [w:] Kino, którego nie ma, red. P. Zwierzchowski, D. Wierski, Bydgoszcz 2013).

11 Zob. artykuł Francuza A. Cervoniego James Bond - bohater naszych czasów? („Film” 1965, nr 18).

12 Zob. np. obszerny tekst radzieckiej krytyczki M. Turowskiej „Bohater” naszych czasów, którego polskie thumaczenie zamieszczono w „Kulturze Filmowej” (1968, nr 3).

13 Zob. np. nr 333 „Filmu na Świecie” z 1986 roku, w którym zamieszczono obszerne fragmenty książki Ericha Kociana Die James Bond Filme (1982). 
tywną próbkę, umożliwiającą wskazanie najważniejszych kulturowych dyrektyw interpretacyjnych wpływających na odbiór Bonda.

Nawet pobieżny przegląd analizowanych tekstów ujawnia pewną prawidłowość chronologiczną, pozwalając na podzielenie zebranego materiału na dwie grupy. Pierwszą stanowią artykuły, które ukazywały się od połowy lat 60 . do połowy lat 70. XX wieku. Natomiast następna fala zainteresowania Jamesem Bondem przypada na drugą połowę lat 80 . ubiegłego stulecia. Ze względu na zdecydowanie różny kontekst, w jakim funkcjonowały te teksty, ów podział chronologiczny będzie dla mnie punktem wyjścia, ukierunkowując tok dalszej analizy.

\section{Lata 1965-1974}

Publikacje poświęcone Bondowi nieprzypadkowo zaczynają z większą częstotliwością pojawiać się w polskiej prasie w roku 1965. Rok wcześniej premierę na ekranach zachodnich kin miał film Goldfinger (reż. Guy Hamilton, Wielka Brytania 1964), któremu towarzyszyła poprowadzona z rozmachem promocja, obejmująca między innymi sprzedaż filmowych gadżetów, zabawek czy ubrań firmowanych nazwiskiem agenta. $Z$ kolei na koniec 1965 roku zaplanowano premierę Operacji Piorun (Thunderball, reż. Terence Young, Wielka Brytania 1965) ${ }^{14}$, która - dzięki budżetowi trzykrotnie większemu niż w wypadku Goldfingera, rozmachowi inscenizacyjnemu (produkcja otrzymała Oscara za efekty specjalne) i szerokiej promocji - miała wykorzystać i zwielokrotnić impet nadany marce przez poprzednie części. Artykuły w polskiej prasie (zarówno oryginalne, jak i thumaczone) są zatem reakcją na rodzącą się na Zachodzie bondomanię i na jej stopniowy rozwój ${ }^{15}$. Z czasem zjawisko to traci posmak egzotycznej nowości, dlatego też pod koniec lat 60 . XX wieku zainteresowanie nim wyraźnie słabnie.

${ }^{14}$ W Polsce Ludowej tłumaczono ten tytuł jako Ognista kula.

${ }^{15}$ W kontekście europejskiej popularności Bonda warto też wspomnieć o eseju Marka Hłaski Od Ikara do Jamesa Bonda. Mit wyzwolonego człowieka, który po raz pierwszy został opublikowany w niemieckojęzycznym szwajcarskim tygodniku „Die Weltwoche” w połowie lat 60. Jak sugeruje sam tytuł, Bond jest dla polskiego pisarza kolejną inkarnacją znacznie starszego mitu o prawdziwej wolności: „Może uwodzić, zabijać, robić z ludzi inwalidów itp. Prawo i moralność — to dla innych, dla Bonda — jedynie jego własna wola. Ma on wprost nieograniczone możliwości finansowe. Jeździ najelegantszymi samochodami, na jakie mogą sobie pozwolić tylko milionerzy. Swojego przełożonego traktuje jak idiotę, ale w tym przypadku trzeba mu jednak przyznać rację" (przeł., oprac. K. Bodanko, „Zeszyty Literackie” 1990, nr 30, s. 108). Sam Hłasko nie przywiązywał wielkiej wagi do czterech esejów napisanych dla „Die Weltwoche”, twierdząc, że stworzył je wyłącznie dla pieniędzy, a redakcja pisma ingerowała w ich treść bez konsultacji z nim (zob. K. Bodanko, Eseje Marka Hłaski dla „Die Weltwoche”, „Zeszyty Literackie” 1990, nr 29, s. 66-67). Po polsku zostały one przedrukowane dopiero w 1990 roku — w związku z tym nie włączam ich do głównego toku analizy. Tekst Od Ikara do Jamesa Bonda pozostaje jednak interesującym epizodem w historii polskiej recepcji fenomenu bondowskiego, tym bardziej że zaświadcza o ogromnej popularności agenta 
Ciekawość ta zaowocowała przede wszystkim artykułami omawiającymi fenomen Jamesa Bonda, co oznacza, że przeciętny polski odbiorca miał jedynie zapośredniczoną wiedzę na temat przygód brytyjskiego agenta. Prawdopodobnie największe starania o udostępnienie rodzimemu czytelnikowi próbek oryginalnych tekstów podjął łódzki tygodnik „Odgłosy”, który w 1966 roku opublikował artykuł Coctail z Jamesa Bonda ${ }^{16}$. Składają się na niego thumaczenia pięciu obszerniejszych (kilku- i kilkunastoakapitowych) fragmentów powieści Doktor No (Dr. No, 1958, pol. 1989) i Żyje się tylko dwa razy (You Only Live Twice, 1964, pol. 2003), opatrzonych stosownymi śródtytułami (na przykład James Bond przedstawia się), a także biogramem Fleminga, cytatem z jego wypowiedzi na temat bohatera oraz krótkim wprowadzeniem redakcji. Dobór przełożonych fragmentów jest oczywiście celowy (dwa z nich to opisy okrutnych planów antagonistów, dwa kolejne - relacji między Bondem a kobietami) i również stanowi swego rodzaju interpretację, zwracając uwagę odbiorcy przede wszystkim na motywy fantastyczne oraz erotyczne. Niemniej jednak tekst ten dawał rodzimemu czytelnikowi bezpośredni (choć wyrywkowy) wgląd w specyfikę owej prozy. W pozostałych wypadkach odbiorcy byli skazani na rozmaite (często wzajemnie się wykluczające) przybliżenia i omówienia.

Czytając poświęcone Bondowi artykuły z tego okresu, można zauważyć przede wszystkim zainteresowanie fenomenem bondowskim jako większą całością. Tematem tekstów nie są zatem konkretne filmy czy powieści, właściwie tylko artykuł Ognista kula Zbigniewa Pitery (zamieszczony w dziale „Filmy, o których się mówi”) omawia jedno konkretne dzieło - wspomnianą już Operację Piorun - przybliżając fabułę filmu, zestawiając go z poprzednikami, określając jego specyfikę oraz wady i zalety. W pozostałych artykułach można dostrzec tendencję do traktowania bondowskiej marki zbiorczo - autorzy piszą więc w nich zarówno o powieściach Fleminga, jak i o ich filmowych adaptacjach, często dodając do tego refleksje na temat zabawek czy ubrań sprzedawanych pod nazwiskiem Bonda bądź też prób naśladowania popularnej formuły w ramach kinematografii włoskiej czy francuskiej. Nawet wspomniany Coctail z Jamesa Bonda, poświęcony tylko prozie Fleminga, ilustrowany jest dwoma zdjęciami, na których pojawia się Sean Connery. Co więcej, w niektórych tekstach jedynie wzmiankuje się o Bondzie na marginesie innych rozważań, ilustrując główną tezę wypowiedzi, dotyczącej na przykład kultury masowej.

Wzmianki tego rodzaju świadczą niewątpliwie o tym, że wpisany w prezentowane teksty czytelnik modelowy miał bez większego trudu rozpoznać agenta 007 i powiązać z nim określone znaczenia. Dobitnym przykładem jest krótka notka z „Filmu” (1966, nr 36) zatytułowana Bład Bonda. W całości dotyczy ona bowiem filmu Przyjemne szaleństwo (A Fine Madness, reż. Irvin Kershner, USA

w Szwajcarii oraz proponuje — często pojawiającą się również później — interpretację Bonda jako współczesnego mitu.

16 Coctail z Jamesa Bonda, „Odgłosy” 1966, 35, s. 10. 
1966), w którym główną rolę zagrał Connery. Tytułowym błędem miało być właśnie obsadzenie szkockiego aktora w roli niepasującej do jego emploi niepokonanego asa wywiadu. Autor notatki nie wyjaśnia, jakiego typu postacią jest Bond, traktując to najwyraźniej jako oczywiste. Tego rodzaju przykłady świadczą więc, że samo nazwisko Bonda musiało być znane polskim odbiorcom, którzy przynajmniej oględnie kojarzyli je z określonym typem postaci.

Analizując teksty wydrukowane w tym okresie, można dostrzec trzy podstawowe kody odbiorcze, do jakich odwołują się autorzy próbujący skonceptualizować i wyjaśnić fenomen Jamesa Bonda: 1) kod krytyczny, 2) kod ideologiczny oraz 3) kod ludyczny. W ramach tych trzech perspektyw ten sam cykl literacki i filmowy (oraz wyrosły wokół nich fenomen społeczny) interpretowano i oceniano skrajnie odmiennie. Jest to oczywiście podział przeprowadzony na potrzeby niniejszej analizy, rekonstruowany na podstawie poszczególnych tekstów. Należy więc pamiętać, że często kody te uruchamiane były w ramach tego samego wywodu, dlatego nie można wprost powiązać ich z konkretnymi artykułami czy autorami.

Kod krytyczny. Pierwszy z kodów odbioru korzysta z kategorii i argumentów wypracowanych w XX wieku w ramach dyskursu krytycznego względem kultury masowej, którego chyba najbardziej reprezentatywnym przykładem pozostaje opublikowana w 1953 roku Teoria kultury masowej (A Theory of Mass Culture) Dwighta Macdonalda ${ }^{17}$. Charakterystycznym elementem tego dyskursu było ostre, oceniające rozgraniczenie między kulturą wysoką a masową. Wytwory sztuki masowej postrzegano więc jako prymitywne, bezwartościowe i zuniformizowane, a ją samą — jako zagrożenie dla prawidłowego rozwoju społeczeństwa ${ }^{18}$.

Krytycy patrzący na fenomen Bonda $\mathrm{z}$ tej perspektywy dostrzegali więc w nim masową fascynację miernym artystycznie tekstem. Tak charakteryzował twórczość Fleminga Marian Pilot na łamach „Tygodnika Kulturalnego”:

Ian Fleming był, podług mojego zdania, grafomanem czystej wody: a jednak coś niepokojącego i zastanawiającego jest w tej jego pisaninie: jakaś szczególnego rodzaju umiejętność grania na uczuciach czytelnika, umiejętność zafrapowania czystą bzdurą, czarowania przy pomocy kompletnych dub smalonych ${ }^{19}$.

Wychodząc z takiego założenia, próbowano odpowiedzieć na pytanie o źródła masowej fascynacji tą postacią. Według Pilota sekret Fleminga tkwił w jego biografii i umiejętnym wykorzystaniu doświadczeń z czasów pracy w wywiadzie. Zdaniem większości autorów zbiorowe zainteresowanie Bondem zasadzało się jednak na najbardziej prymitywnych instynktach, stąd w artykułach często powracały dwa nierozerwalnie z sobą splecione wątki przemocy i seksu, które mia-

${ }^{17}$ Zob. D. Macdonald, Teoria kultury masowej, przeł. C. Miłosz, [w:] Kultura masowa, wyb., przeł., przedm. C. Miłosz, kom. J. Szacki, Kraków 2002 (pierwsze wyd. pol. Paryż 1959).

${ }_{18}$ Krytykę kultury masowej z tego stanowiska trafnie rekonstruuje D. Strinati (Wprowadzenie do kultury popularnej, przeł. W.J. Burszta, Poznań 1998, s. 15-50).

19 M. Pilot, Agent 007, „Tygodnik Kulturalny” 1969, nr 20, s. 10. 
ły stanowić główne filary sukcesu postaci Bonda. Sławomir Sierecki w artykule $W$ magicznym kręgu Jamesa Bonda nazywa więc cykl Fleminga „kuchenną literaturą" i konstatuje:

Dla miłośników akcji — jest akcja opasująca tysiącem niezwykłych zdarzeń cały glob. Dla entuzjastów literatury pornograficznej Fleming szczodrze opisuje sceny erotyczne Bond jest przecież wysokiej klasy,,podrywaczem”. Dla sadystów są wszystkie rodzaje tortur ${ }^{20}$.

Z kolei Mirosław Derecki na łamach „Kameny” tak opisuje przyczynę popularności kinowych wersji przygód agenta:

„Bondofilmy” charakteryzuje niezwykły rozmach inscenizacyjny, liczebność statystów. Jeśli scenariusz wymaga ukazania bitwy płetwonurków, angażuje się ich stu. Jeśli inscenizuje scenę walki karate, bierze w niej udział kilka tysięcy osób. To skutkuje. Pomijając już sprawę sexu, któremu poświęca się tyleż miejsca co zbrodniczemu wyrafinowaniu i okrucieństwu ${ }^{21}$.

Te przykłady dobitnie pokazują, w jaki sposób autorzy prezentowali teksty literackie i filmowe o Bondzie jako produkty infantylne i prymitywne, obliczone na zaspokajanie najniższych gustów. Problem erotyki podkreślano zresztą nie tylko dyskursywnie - charakterystyczne, że spora grupa artykułów ilustrowana jest filmowymi kadrami estetyzującymi wizerunek pięknej kobiety lub sugerującymi jej co najmniej dwuznaczną relację z Bondem. W publikacji James Bond - bohater naszych czasów? wykorzystano kadr z Goldfingera (naga Jill Masterson [grana przez Shirley Eaton] pomalowana złotą farbą), W magicznym kręgu Jamesa Bonda - z finału Operacji Piorun (Bond i, ubrana tylko w kostium kąpielowy, Dominique „Domino” Derval [Claudine Auger] w pontonie), z tego samego filmu zaczerpnięto ilustrację do „Bohatera” naszych czasów Mai Turowskiej oraz Najpopularniejszego bohatera filmowego, na której Bond jest masowany przez piękną kobietę.

Według polskich autorów to właśnie strategia odwoływania się do najprostszych instynktów zapewnia postaci Jamesa Bonda tak ogromną popularność. Przy okazji owej popularności pojawia się zaś drugi wątek zaczerpnięty wprost z retoryki krytyków kultury masowej, a więc groźba unifikacji sztuki. Dobitnym symptomem tego zagrożenia były, zdaniem rodzimych publicystów, produkcje naśladujące cykl bondowski i kopiujące jego formułę, dlatego też dosyć często wspominano o przetaczającej się przez Europę fali popularności brytyjskiego agenta. Z tego powodu ankieta „L'Humanite-Dimanche” dotycząca „inwazji tematyki szpiegowskiej do literatury, filmu i telewizji” stała się punktem wyjścia dla notki wydrukowanej w rubryce „Kronika zagraniczna” w „Kulturze”. Autor tekstu sugerował między innymi, jakoby w 1966 roku co drugi film wyprodukowany we Francji miał być filmem szpiegowskim ${ }^{22}$. O „epidemii »bondyzmu«" donosiło w tym samym roku „Kino”, w którym znaczna część Najpopularniejsze-

20 S. Sierecki, W magicznym kręgu Jamesa Bonda, „Litery” 1967, nr 3, s. 7.

${ }^{21}$ M.D. [Mirosław Derecki], W sidłach agenta 007, „Kamena” 1969, nr 9, s. 14.

22 Zob. Przyczynek do „,bondologii”, „Kultura” 1966, nr 13, s. 2. 
go bohatera filmowego to wyliczenie rozmaitych francuskich czy włoskich produkcji próbujących powtórzyć sukces brytyjskiej serii.

Groźba unifikacji wiąże się oczywiście z groźbą amerykanizacji — to kultura USA, ojczyzny sztuki masowej, ma bowiem narzucać swoje upraszczające wzorce. Trafnie te zastrzeżenia charakteryzował Strinati:

Obawy i niepokoje wyrażane przez krytyków kultury masowej w równym stopniu pobudzała groźba amerykanizacji. Powodem tego jest fakt, że amerykańska kultura popularna uosabia całe zło związane z kulturą masową. [...] Tak wiele wytworów kultury masowej przychodzi z Ameryki, iż jest ona postrzegana jako zagrożenie; podobną groźbą staje się amerykanizacja. Zdaniem krytyków kultury masowej jest to niebezpieczeństwo nie tylko dla standardów estetycznych i wartości kulturowych, ale dla kultury narodowej jako takiej ${ }^{23}$.

W opublikowanym na łamach „Kultury” artykule pod znamiennym tytułem State zagrożenie: kultura masowa Jerzy Kossak wprost nawiązuje do tego problemu, wskazując, że światowe sukcesy brytyjskich twórców, paradoksalnie, potwierdzają tezę o amerykanizacji globalnej kultury. Z powodzeniem z produktami z USA mogą bowiem konkurować tylko wytwory kultury europejskiej powielające wypracowaną w Stanach Zjednoczonych formułę i w ten sposób dostosowujące się do wymogów masowej publiczności:

To nie intelektualiści, poeci i dramaturdzy spod znaku Angry Young Men podbili Amerykę [...]. Jeśli mówić o ludziach i dziełach, które wyszły triumfalnie na rynek masowy i zrobiły kasę, wchodząc do konkurencyjnej walki z produktami Ameryki, a nawet wygrywając kolejne rundy — to okaże się, że na tak zakreślonym ringu pozostali Beatlesi, Ian Fleming i filmowa adaptacja jego dzieł dokonana przez Terenca Jounga (sic!) wsparta o kreacje O'Connory'ego (sic!) — jako agenta 007 — legendarnego Jamesa Bonda — i jeszcze niezbyt ambitne, ale bardzo wielkie i kolorowe „Shows” o tematyce biblijnej ${ }^{24}$.

Nawet bardziej znamienny pod tym względem jest cytowany już Przyczynek do ,,bondologii”, w którym utożsamianie kultury masowej i Ameryki sięga tak daleko, że autor twierdzi, iż filmy o Jamesie Bondzie pochodzą z USA:

Nakłady ich [czyli autorów literatury szpiegowskiej] książek osiągają miliony egzemplarzy, przekładane są na wiele języków obcych, zrealizowano wiele filmów, w tym 5 z Jamesem Bondem w USA. Obok tych „sztandarowych” autorów wyrosła cała plejada pomniejszych ${ }^{25}$.

Dyskurs formułowany w kategoriach krytyki kultury masowej miał, rzecz jasna, na celu utrzymanie pewnego porządku społecznego, w którym określonym grupom, reprezentującym sferę kultury wysokiej, przypisany zostaje autorytet znawców i arbitrów smaku, rozstrzygających o tym, co jest estetycznie właściwe i pożądane. Krytykom kierującym się tą strategią bondowski fenomen dostarczał przykładów, które mogli wykorzystać w swoich retorycznych atakach na kulturę masową. Jednak kod krytyczny uruchamiano również w innym kontekście -

${ }^{23}$ D. Strinati, op. cit., s. 30.

24 J. Kossak, Stałe zagrożenie: kultura masowa, „Kultura” 1966, nr 34, s. 3.

25 Przyczynek..., s. 2. 
bardzo często łączono go z kodem ideologicznym, odrzucając utwory o Bondzie zarówno z powodów estetycznych, jak i ideowych ${ }^{26}$. Ponieważ te dwa dyskursy bywały z sobą mocno splecione, to właśnie kodem ideologicznym chciałbym się zająć w następnej kolejności.

K o d i d e o lo g i c z n y. W piśmiennictwie Polski Ludowej — jak łatwo się domyślić - pojawiały się również analizy bondowskiego fenomenu utrzymane w kluczu ideologicznym. W interpretacjach tego rodzaju można dostrzec zasadniczo trzy główne wątki: po pierwsze, czytelnikom przybliżano (pośrednio lub bezpośrednio) zarzuty, jakie pod adresem Bonda formułowano na zachodzie Europy ${ }^{27}$, gdzie oskarżano go o propagowanie idei imperialistycznych i rasistowskich; po drugie, w rodzimym dyskursie do zarzutów tych dodawano również antykomunizm, dowodząc w ten sposób, że w opowieści o Bondzie niemal jawnie wpisana została funkcja perswazyjna; po trzecie wreszcie, fenomen bondowski próbowano analizować, odwołując się do koncepcji wypracowanych przez krytykę marksistowską.

Wątek pierwszy pojawia się w polskim dyskursie dosyć szybko: już w 1965 roku, za sprawą tekstu francuskiego krytyka Alberta Cervoniego James Bond bohater naszych czasów? opublikowanego w „Filmie”. Autor wprost oskarża filmy bondowskie o rasizm i nacechowanie polityczne, a protagonistę nazywa „Nadczłowiekiem”. W artykule Najpopularniejszy bohater filmowy wspomina się, że angielska i francuska prasa „szeroko komentuje faszystowski aspekt filmów o Bondzie"28. Sporo miejsca poświęca temu problemowi (powołując się na krytyków angielskich) również Turowska, radziecka autorka, której esej „Bohater” naszych czasów, przetłumaczony na polski, wydrukowano w „Kulturze Filmowej". O angielskim szowinizmie i motywach rasistowskich w powieściach Fleminga wspomina też Janusz Skwara w krótkim opracowaniu Film zachodni a polityka w rozdziale zatytułowanym Bond i jego naśladowcy.

O ile wszakże zarzut ten u Cervoniego jest wątkiem autonomicznym, o tyle u Turowskiej i Skwary stanowi zaledwie część szerszego obrazu, w którego ramach literackie i filmowe teksty o Bondzie przedstawia się jako wytwory propagandy. Polski krytyk pisze wprost:

Jakąkolwiek postać poruszymy, łatwo zauważyć, że anglosaski szowinizm autora korzeniami tkwi w polityce. Odnosi się to także do elementów mitu Bonda. Każdy przeciwnik, z którym walczy ,agent 007”, reprezentuje zawsze „czerwone niebezpieczeństwo”29.

${ }^{26}$ Połączenie takie wyrastało, rzecz jasna, wprost z legitymizującego system komunistyczny projektu kulturalnego, który deklaratywnie miał zapewnić szerokim masom dostęp do prawdziwej i wartościowej sztuki.

${ }^{27}$ Zarzuty te omawia w swoim znanym tekście U. Eco, Struktury narracyjne u Fleminga, [w:] Superman w literaturze masowej. Powieść popularna: między retoryka a ideologia, przeł. J. Ugniewska, Kraków 2008, s. 223.

28 Najpopularniejszy bohater filmowy, „Kino” 1966, nr 1, s. 53.

29 J. Skwara, Film zachodni a polityka, Warszawa 1970, s. 89. 
W podobny sposób kwestię antykomunizmu Bonda prezentowano w „Trybunie Ludu":

Przeciwnicy James'a Bond'a — rekrutujący się ,zza żelaznej kurtyny” — przedstawieni są w odrażająco wulgarny sposób: jako nikczemni i skretyniali ,podludzie”. [...] Wszystkie dotychczas nakręcone, począwszy od 1962 r., filmy z serii „James Bond” [...] poczęte zostały w duchu najklasyczniejszej zimnej wojny i przygotowań do wojny gorącej...

Wszystkie zaś przeliczne sceny walki i mordu — dokonywanego najczęściej wyrafinowanymi metodami - rozgrywają się w atmosferze nienawiści i pogardy do świata socjalistycznego oraz w oparach... pornografi ${ }^{30}$.

Również cytowany już Pilot miał wątpliwości, że powieści Fleminga stanowią teksty rasistowskie i propagandowe, a co więcej — że propaganda ta okazuje się skuteczna:

Bond [...] jest w każdym calu bojownikiem przeciwko komunizmowi czy raczej przeciwko wszystkiemu, co wschodnie, azjatyckie, murzyńskie etc. Bond zwycięża zawsze, w każdym pojedynku na intelekt i w każdym pojedynku na pięści. [...] Czerwone niebezpieczeństwo jest wszędzie, każdy komunista jest potencjalnym niebezpieczeństwem dla „wolnego świata”: należy żyć w nieustannym pogotowiu, w nieustannym napięciu nienawiści, należy walczyć, nie przebierając w środkach. Piękny, męski, zręczny, niezwyciężony, jest James Bond apostołem nienawiści totalnej, bojownikiem nieugiętym i zawsze triumfującym. [...]

Nie lekceważmy Bonda: jego oczyma, pełnymi nienawiści i pogardy, patrzy na nas niejeden z czytelników i niejeden z widzów „,bondowych” książek i filmów ${ }^{31}$.

Wątek antykomunistyczny wydaje się o tyle ciekawy, że filmy o Bondzie powstawały w innym międzynarodowym kontekście niż powieści Fleminga, dlatego twórcy adaptacji właściwie zrezygnowali z jawnych odniesień politycznych. Polscy autorzy interpretowali ten fakt na różne sposoby. Niektórzy nie czynili w ogóle rozróżnienia między powieściowymi pierwowzorami a ich ekranizacjami, wymiennie odnosząc się bądź do jednych, bądź do drugich (jak na przykład w tekście z „Trybuny Ludu” czy „Tygodnika Kulturalnego”). Przywoływali więc antykomunistyczne wątki pojawiające się u Fleminga i nie wspominali, że ten aspekt opowieści o Bondzie w medium filmowym był kształtowany nieco inaczej.

Inni z kolei wprawdzie wzmiankowali o owym przesunięciu, jednak odczytywali je wyłącznie jako zabieg maskujący. Taką interpretację zaproponował m.in. Skwara, który najpierw szeroko streszczał fabułę Pozdrowień z Rosji (From Russia with Love, reż. Terence Young, Wielka Brytania 1963), skupiając się na wątku radzieckim, potem zaś, w dalszej części wywodu, stwierdzał:

właściwie już w dwóch ostatnich filmach bondowskich, Thunderball i Żyje się tylko dwa razy, nie spotyka się sylwetek jasno określonych radzieckich agentów, ale głównie złoczyńców spod ciemnej gwiazdy, z opisanym już przez nas wyżej Ersntem Stavro Blofeldem na czele. Nie zmieniło to oczywiście głównej idei filmów bondowskich, skoro zabójca Martina Luthera

${ }^{30}$ Sław, Komu - i czemu - stuży James Bond, „Trybuna Ludu” 26 X 1965, s. 6. Pisownia oryginalna.

${ }^{31}$ M. Pilot, op. cit., s. 10. 
Kinga, zapewne wielbiciel Bonda, używał w Anglii pseudonimu Galt, z charakterystycznymi imionami... Ernst [właśc. Eric] Starvro. Być może przypadek. [...]

Taktyka „frontu ideologicznego” jest elastyczna, zmienia się ją zależnie od okoliczności. Ponieważ coraz częściej jawna propaganda nie przynosi spodziewanych efektów, zmienia się język przekonywania: zamiast inwektyw — wyrazy pozornej sympatii, dobrotliwych (rzekomo) rad itp. Stare praktyki w nowym opakowaniu ${ }^{32}$.

Podobną tezę postawił na łamach „Kultury” autor Przyczynku do ,, bondologii”:

Rzecz znamienna, że jeśli chodzi o filmy, to realizatorzy starannie unikają otwartych ataków przeciwko krajom socjalistycznym, tuszując też wyraźne akcenty rasistowskie. Zdają sobie sprawę, że mogłoby to odciągnąć poważną część publiczności. Ale ogólna tendencja książek i filmów szpiegowskich jest zawsze ta sama — obrona „wolnego świata” przed złymi mocami ${ }^{33}$.

Zdaniem obu autorów zrezygnowanie z pokazywania konfliktu między państwami kapitalistycznymi i socjalistycznymi było tylko wybiegiem taktycznym, strategia pozostawała bowiem niezmienna. Ideologiczny styl odbioru sprawiał zatem, że wymiaru propagandowego nabierały także te teksty, które nie odnosiły się bezpośrednio do kwestii politycznych. W ten sposób znoszono właściwie kategorię neutralnej rozrywki - kinematografia (czy kultura w ogóle) była frontem wojny ideowej, a każde dzieło należało uznać bądź za postępowe, bądź też reakcyjne. Cytowani autorzy nie mieli wątpliwości, do której kategorii zaliczyć powieści i filmy o Jamesie Bondzie.

Trzeci ze wspomnianych wątków wiązał się z próbami wyjaśnienia fenomenu bondowskiego w kategoriach marksistowskich. Próbowała to zrobić Turowska. Przywołała ona nawet nazwisko Antonia Gramsciego, cytując jego opinię o źródle poczytności literatury sensacyjnej. Zdaniem radzieckiej krytyczki popularność Bonda jest efektem postępującej alienacji społeczeństwa kapitalistycznego, w którym jednostki są coraz bardziej osamotnione i tracą już nadzieję na jakąkolwiek przebudowę systemu. W tym ujęciu Bond stanowi więc taki sam symptom rozkładu kapitalizmu jak charakterystyczny dla lat 50. XX wieku kult bohaterów w typie Jamesa Deana — zbuntowanych „młodych gniewnych”. Turowska przedstawia zatem dialektyczny obraz procesów rzekomo typowych dla kapitalizmu, w których jednostka zbuntowana i bezradna oraz działający nadczłowiek mają tę samą genezęę

Podobny wątek można znaleźć w notce James Bond i kultura masowa opublikowanej w „Filmie”. Tekst stanowi skrótowe omówienie eseju Siergieja Możnja-

32 J. Skwara, op. cit., s. 102-103.

33 Przyczynek..., s. 2.

34 Tego rodzaju tezy pojawiały się w różnych zideologizowanych dyskursach dość często. Jak wskazywał B. Tracz (,Zdemoralizowane brudasy”. Początki ruchu hipisowskiego w Polsce oraz przeciwdziałania ze strony instytucji wychowawczych i represyjnych państwa, [w:] Od kontrkultury do New Age. Wybrane zjawiska społeczno-kulturowe schytku PRL $i$ ich korzenie, red. E. Chabros, Wrocław 2014, s. 232-233), ruch hipisowiski (i szerzej: wszelkie ruchy kontrkulturowe) opisywano w PRL-u z niechęcią i widziano w nich jedynie produkt rozkładu systemu kapitalistycznego. 
guna, radzieckiego krytyka odrzucającego przedstawione tezy Turowskiej. Autor ten twierdzi, że kultura masowa nie odpowiada na potrzeby swoich odbiorców, jest bowiem narzędziem w rękach klas rządzących. Oznacza to zatem, że zarówno postać buntownika (młodego gniewnego, beatnika czy hipisa), jak i „komiksowy nadczłowiek” zostali precyzyjnie zaprojektowani, gdyż za ich pomocą „,burżuazja i posłuszni jej reżyserzy chcą manipulować masową publicznością"35.

$\mathrm{W}$ artykule poświęconym portretom wroga zawartym w piśmiennictwie filmowym pierwszej połowy lat 50. XX wieku Zwierzchowski wspomina, że idiom krytyki socrealistycznej przetrwał znacznie dłużej niż sam realizm socjalistyczny i powracał również w latach późniejszych. Jako przykład badacz przywołuje między innymi książkę Skwary Film zachodni a polityka ${ }^{36}$. Rzeczywiście, rekonstruowany tu kod ideologiczny — z charakterystycznym językiem; z typową wizją kultury (jako pola ciągłej walki między socjalizmem a kapitalizmem, jako narzędzia celowej manipulacji masami, jako sfery na wskroś upolitycznionej, w której nic nie jest neutralne); oraz z dostrzeganiem prostych powiązań między rzeczywistością filmową i pozafilmową — przypomina styl odbioru charakterystyczny dla socrealizmu. Oskarżenia zachodniej kultury zarówno o rasizm, jak i o produkowanie sztuki zdegenerowanej i prymitywnej nie są tu niczym nowym, zwraca natomiast uwagę to, jak zostały one włączone do narracji o antysocjalistycznym, antykulturalnym, antypostępowym i antyludzkim wydźwięku Jamesa Bonda. Przykład ten potwierdza więc tezę Eryka Krasuckiego, który stwierdził, iż w latach 60. ubiegłego stulecia w wielu wypowiedziach — zwłaszcza osób silnie związanych z dyskursem partyjnym - powracają koncepcje i retoryka przywodzące na myśl dyskurs socrealistyczny ${ }^{37}$. Nie dziwi więc, że również bondowski fenomen był ujmowany w tych kategoriach.

K o d 1 u d y c z n y. Interpretacje posługujące się kodem ludycznym różniły się od przywoływanych tekstów przede wszystkim tym, że nawiązywały do innej konceptualizacji kultury masowej. W tej perspektywie nie była ona sztuką skomercjalizowaną i zdegradowaną lub uwikłaną w zadania propagandowe, lecz autonomicznym fenomenem, który posiadał swoją własną specyfikę oraz tradycję i powinien być analizowany za pomocą odpowiednich kategorii. Owa zmiana sposobu oglądu sprawiała zaś, że te same elementy powieści i filmów o Bondzie opisywano i oceniano zupełnie inaczej, inną też formułowano odpowiedź na pytanie o źródła popularności brytyjskiego agenta.

To przesunięcie najlepiej widać, gdy przyjrzymy się kwestiom podnoszonym również w interpretacjach ideologicznych i estetycznych, a więc wątkom antykomunistycznym i erotyce. Ludyczne dyrektywy interpretacyjne sprawiają, że są

35 mol., James Bond i kultura masowa, „Film” 1973, nr 8, s. 22.

36 P. Zwierzchowski, Portret wroga..., s. 192.

${ }^{37}$ E. Krasucki, Co towarzysz Wiesław wiedział o bigbicie? Świadomość zjawiska kultury masowej w okresie „popaździernikowym” (1956-1963), [w:] Kultura popularna w Polsce w latach 1944-1989. Problemy i perspektywy badawcze, red. K. Stańczak-Wiślicz, Warszawa 2012, s. 61-63. 
one całkowicie odmiennie postrzegane i omawiane. Krzysztof Teodor Toeplitz opisywał komunistycznych przeciwników Bonda nie jako element propagandowy, ale jako konwencjonalne, odrealnione figury antagonistów typowe dla filmu popularnego:

Autor artykułu o „kinie grozy” zapomniał jednak, jak mi się wydaje, o jednym bardzo ważnym w dzisiejszej produkcji rozrywkowej Zachodu gatunku zabawy w strach, a mianowicie o straszeniu komunizmem. Już filmy z Jamesem Bondem zaprezentowały serię niesłychanych strachów w postaci niezwykłych, przypominających pod wieloma względami poczciwego King Konga, agentów wywiadów komunistycznych. Podobnie jak w klasycznym filmie grozy, tak i w filmie lub literaturze straszącej komunizmem scenariusz, jego sens i logika, odgrywają raczej rolę drugorzędną, przede wszystkim zaś chodzi o to, żeby było możliwie jak najstraszniej ${ }^{38}$.

W dalszej części felietonu autor dodaje:

Oczywiście książkę tę [to jest Ze śmiertelnego zimna Johna le Carré - The Spy Who Came In from the Cold, 1963, pol. 1986], jak wiele podobnych, należy traktować wyłącznie jako literaturę rozrywkową, a wszelkie próby potraktowania jej serio mogą narazić na taką samą śmieszność, jak przyjmowanie serio filmów z Bondem. Jest to po prostu pewien, uświęcony już przez tradycję, rodzaj rozrywki, tak jak tradycją są filmy o Indianach, gangsterach lub nadludzkich rozmiarów potworach, wyłaniających się nieoczekiwanie z oceanu ${ }^{39}$.

Porównania, którymi posługuje się publicysta, nie pozostawiają wątpliwości: ewentualne wątki polityczne powinny być rozumiane jako element konwencjonalny, zaczerpnięty ze zbiorowej wyobraźni i repozytorium gatunkowego, tak są bowiem odbierane przez widzów. Pojawiają się tu zatem takie kategorie, jak umowność, konwencja czy fantazja. Podobnie autor komentarza do Coctailu z Jamesa Bonda zauważa:

Nadużywa się tego [to jest prozy Fleminga] do propagandy antykomunistycznej, chociaż Fleming nie zamierzał pisać ,,antyczerwonej” literatury. Gdyby zaczynał pisać o Bondzie przed wojną, albo podczas wojny, wrogami Bonda byliby zapewne naziści ${ }^{40}$.

Wreszcie w artykule $Z$ frontu bondomanii donoszącym na łamach „Filmu” o amerykańskiej popularności agenta bardzo wyraźnie oddziela się abstrahujące od bieżącej polityki filmy o Bondzie i wykorzystujące ich sukces eksploatacyjne amerykańskie filmy szpiegowskie, w których wątki antykomunistyczne rzeczywiście pojawiały się regularnie ${ }^{41}$.

Ludyczny styl odbioru zmienia także postrzeganie problemu erotyki. Rozpatrywana w tym kluczu okazuje się ona nie rozbuchaną pornografią, lecz zachowawczą w gruncie rzeczy atrakcją. Warto przywołać tu inny tekst Toeplitza:

Nie ulega kwestii, że Bond jest tym, co określa się jako „kobieciarza”. Zarzucają mu to nie tylko krytycy, ale wytyka również z niesmakiem i ojcowską przyganą jego szef, „M”.

\footnotetext{
${ }^{38}$ KTT [Krzysztof Teodor Toeplitz], Kino grozy w domu, „Kultura” 1966, nr 32, s. 12.

${ }^{39}$ Ibidem.

40 Coctail z Jamesa..., s. 10.

${ }^{41}$ M.D., Z frontu Bondomanii, „Film” 1966, nr 37, s. 11.
} 
W filmach o Bondzie spotykamy galerię pięknych i mocno rozebranych kobiet, w jednym z nich debiutowała Ursula Andress, uznana obecnie za „najpiękniejszą kobietę świata”, wychodząc nago z kąpieli morskiej. Na tym odcinku Fleming niewątpliwie nie kontynuuje ani poczciwej tradycji Conan Doyle'a, [...] ani twardej wstrzemięźliwości Kiplinga, ani wreszcie przygodowej powieści młodzieżowej. Jest cały po stronie „thrilleru” albo szerzej, po stronie współczesnych obyczajów reklamowych w tym względzie, gdzie sex uznany jest za czynnik pierwszorzędny. Każda jego [tj. Bonda] przygoda ozdobiona jest romansem. Każdy jego romans uwieńczony jest łóżkiem. [...] Zwrócę tu jedynie uwagę na jeden fakt z zakresu ściśle „bondologicznego" [...]. Otóż w trzynastu powieściach Fleminga Bond „konsumuje” 13 kobiet. Zwłaszcza jak na Brytyjczyka [...] jest to sporo, ale równocześnie należy zwrócić uwagę, że wszystkie książki Fleminga rozgrywają się tak czy inaczej w obcych krajach, w podróży. Po jednej kobiecie na długą, niekiedy wielomiesięczną podróż, to jednak przecież może się zdarzyćc ${ }^{42}$.

Tak jak we wcześniejszym cytacie Toeplitz nieco na wyrost wspominał o licznych komunistycznych agentach pojawiających się w filmach o Bondzie, tak i tutaj przypisuje tym produkcjom większe rozerotyzowanie niż to, które w rzeczywistości było ich udziałem — w żadnej ze scen Doktora No (Dr. No, reż. Terence Young, Wielka Brytania 1962) Ursula Andress nie pokazuje się nago (eksponowania nagości nie ma też w kolejnych tytułach). Niemniej charakterystyczny jest tu sposób opisu: zdystansowany, ironiczny, a nie potępiający. Dla felietonisty „Kultury” oba omawiane elementy to po prostu zwykłe atrakcje typowe dla kina popularnego, naturalny efekt procesów charakterystycznych dla kultury masowej.

W tym ujęciu fenomen bondowski próbowano wyjaśniać, odwołując się do sprawności realizacyjnej, wysokości budżetu, który pozwalał na rozmach inscenizacyjny, oraz do użytych kodów gatunkowych. Modelowym przykładem takiej interpretacji było omówienie Operacji Piorun autorstwa Zbigniewa Pitery. Krytyk pisał między innymi:

Podział ról jest tym razem znacznie bliższy klasycznym wzorom Verne'a; cały film nosi zresztą cechy bardzo zręcznej syntezy science-fiction, thrilleru, kryminału i westernu, wykorzystującej atrybuty tych gatunków w sposób zmasowany, brawurowy, dowcipny ${ }^{43}$.

Analogicznie powieści Fleminga jako kolaż popularnych gatunków sensacyjnych i przygodowych charakteryzował Toeplitz. Charakterystyczne jest również to, że Pitera sporo miejsca poświęcił opisowi podwodnego starcia, wyraźnie akcentując jego nowatorstwo inscenizacyjne i chwaląc w szczególności rolę „operatora Teda Moore'a, którego praca jest imponującym osiągnięciem nowoczesnej techniki zdjęciowej" 44 . Z podobnym uznaniem dla warsztatu i dla rozmachu realizacyjnego pisał o obrazach $\mathrm{z}$ agentem 007 autor tekstu $Z$ frontu bondomanii:

42 K.T. Toeplitz, Przyczynek do 007 bondologii, „Kultura” 1965, nr 52, s. 3. Artykuł został również, pod zmienionym tytułem James Bond i bondologia, przedrukowany [w:] idem, Akyrema, Warszawa 1969.

43 Z.P. [Zbigniew Pitera], Ognista kula, ,Film” 1966, nr 4, s. 3.

${ }^{44}$ Ibidem. 
Wiadomo, że filmy z Bondem w rodzaju Goldfingera czy Ognistej kuli to kosztowne produkcje o budżecie rzędu 4-5 milionów dolarów. Precyzyjne opracowanie scenariusza, zgromadzenie mnóstwa skomplikowanych rekwizytów technicznych, realizacja zdjęć w najbardziej efektownych pod względem scenerii zakątkach kuli ziemskiej — wszystko to wymaga czasu i nie bez powodu kolejny film z Bondem pojawia się rzadziej niż raz w roku. Wysokie koszty przedsięwzięcia zmuszają producentów do zdwojonej ostrożności - film musi się podobać wszędzie [...]. Realizacja takiego filmu jest więc przedsięwzięciem wszechstronnie przemyślanym i na swój sposób solidnym ${ }^{45}$.

Co ważne, autor wyraźnie wskazuje, że większość spośród amerykańskich prób naśladowania Bonda opiera się na zupełnie innej strategii — stawiającej na niskie koszty produkcji i krótki czas realizacji.

Uogólniając, można powiedzieć, iż ludyczny styl odbioru opierał się na dwóch założeniach: po pierwsze, kultura masowa nie jest fenomenem jednorodnym i nie można jej jako całości uznać za wartościową lub bezwartościową; po drugie, teksty rozrywkowe rządzą się swoją własną logiką i posiadają własną tradycję (między innymi gatunkową), dlatego należy je oceniać za pomocą odrębnych, charakterystycznych tylko dla nich kryteriów. Przyjęcie takich założeń sprawiło, że te same elementy bondowskiej konwencji przedstawiały się autorom zupełnie inaczej niż w analizach estetycznych czy ideologicznych. Nie oznacza to, że traktowali oni cykl o brytyjskim agencie bezkrytycznie, jednak ich ewentualne negatywne uwagi miały zupełnie inną genezę.

Wykształcenie się kodu ludycznego było oczywiście związane z pojawieniem się i stopniowym rozwojem w latach 60 . XX wieku eksperckiego, usystematyzowanego dyskursu poświęconego kulturze masowej. Proces ten szeroko opisywał cytowany już Krasucki — zdaniem badacza, to właśnie w tej dekadzie przynajmniej część autorytetów kulturalnych i naukowych uznała, że istnienie kultury masowej jest zjawiskiem nieuchronnym, dlatego też należy przynajmniej spróbować je lepiej opisać i zrozumieć ${ }^{46}$.

Pierwsza fala zainteresowania polskich autorów fenomenem Jamesa Bonda była zatem niejednorodna i wyraźnie zróżnicowana wewnętrznie. Publicyści i krytycy sięgali po różne kody, interpretując te same zjawiska w sposób krańcowo odmienny. W opisach zachodniej mody na konwencję szpiegowską i markę 007 wyraźnie odbijają się uwarunkowania lokalne. Nasilająca się od początku lat 60 . debata nad kulturą masową (jej istotą, nieuchronnością jej występowania, możliwością jej wykorzystania w ramach określonej polityki kulturalnej), przebiegająca pod wyraźnym naciskiem politycznym, nie wypracowała stabilnego kodu pozwalającego opisywać fenomeny popularne ${ }^{47}$. Stąd też, jak sądzę, wewnętrzne rozchwianie i eklektyzm tej debaty przejawiające się w sięganiu po koncepcje,

${ }^{45}$ M.D., Z frontu..., s. 11.

${ }^{46}$ E. Krasucki, Masowa kultura socjalistyczna. W poszukiwaniu definicji na przełomie lat pięćdziesiatych i sześćdziesiątych XX wieku, [w:] Popkomunizm. Doświadczenie komunizmu a kultura popularna, red. M. Bogusławska, Z. Grębecka, Kraków 2010, s. 21.

${ }^{47}$ Zob. ibidem; E. Krasucki, Co towarzysz... 
tezy i figury wykrystalizowane na różnych polach dyskursywnych. Był to bowiem okres wyraźnych przekształceń w obrębie polskiego systemu wiedzy o kulturze masowej, w którego ramach rywalizowały z sobą wówczas różne sposoby konceptualizacji problemu.

\section{Druga połowa lat 80. XX wieku}

Kolejna fala polskich tekstów poświęconych Bondowi pojawia się w drugiej połowie lat 80 ., a więc już w zupełnie innym kontekście medialnym i społecznym. Okres transformacji wiązał się bowiem ze stopniową i wielowymiarową emancypacją polskich obywateli ${ }^{48}$, co oznaczało również szerszy dostęp do produktów zachodniej popkultury, w tym filmów o Bondzie.

Szansę taką dawało między innymi rozpowszechnienie się w Polsce lat 80 . magnetowidów i powstanie prężnego rynku dystrybucji pirackich kaset VHS. Za pośrednictwem tego kanału szerokim strumieniem wpływały do Polski zachodnie filmy rozrywkowe, oglądane i w prywatnych domach, i na zbiorowych pokazach. O tym, że w ten sposób funkcjonowały też filmy z serii bondowskiej, świadczą na przykład wspomnienia Tomasza Beksińskiego, który na łamach „Machiny” w 1996 roku opisywał, jak po raz pierwszy zapoznał się z przygodami agenta 007:

$\mathrm{Na}$ bondy [...] trafiłem kilkanaście lat temu, na jakimś przeglądzie wideo. Wyświetlano Goldfinger, Thunderball, Dr No i The Spy Who Loved Me. Spodziewałem się, że przyjdą dzikie thumy, a tu bez problemu kupiłem bilety na wszystkie filmy. [...]

Zacząłem zbierać filmy z agentem 007. Kumpel pisał o nich pracę magisterską. Kombinowałem, jak to zrobić, żeby mógł wszystkie zobaczyć. Sam też byłem ciekaw. Kiedy znajdowałem jakieś, mówiłem koledze: „Odkryłem u kogoś dwa bondy, musisz przyjechać, pójdziemy z wizytą. Butelkę przyniesiemy, to nam pokażą".

I zaliczyliśmy wszystkie. Żeby oglądać bondy, kupiłem magnetowid i telewizor kolorowy. Długo nie mogłem dostać żadnego po angielsku — a pirackie tłumaczenia to była GROZA! Chciałem zbierać filmy w oryginale, bo to sprawia mi największą frajdę. Kiedy jednak pokazywałem komuś moje bondy, musiałem siadać i tłumaczyć na żywo. Robiłem kanapki, było wino, goście żarli, pili, a ja tłumaczyłem. Wreszcie powiedziałem sobie: „Kurwa mać, ja też chcę wypić wino, zjeść kanapki, też chcę pooglądać film, a nie siedzieć i thumaczyć. Nagram głos i będę miał spokój"49.

Innym śladem nieoficjalnego funkcjonowania Jamesa Bonda w polskiej kulturze - a przenikał on do niej między innymi dzięki inicjatywom fanowskim ${ }^{50}$

48 Zob. G. Fortuna jr, Wprowadzenie: szok transformacji, „Panoptikum” 2016, nr 15.

49 T. Beksiński, Boże, Bond to jest to, nie ma lepszego kina!, „Machina” 1996, 1, s. 57.

${ }^{50} \mathrm{O}$ fanowskich praktykach obejmujących m.in. działalność wydawniczą i pokazy filmowe szerzej zob. A. Wierzchowska, Literacka subkultura? Polski fandom w latach osiemdziesiatych, [w:] Społeczeństwo polskie w latach 1980-1989, red. N. Jarska, J. Olaszek, Warszawa 2015; P. Siuda, Elita popkulturowego dostęu. Fanowski odbiór popkultury w Polskiej Rzeczypospolitej Ludowej jako sprzeciw wobec systemu politycznego — przykład fandomu science-fiction, „Kultura i Historia” 2013, nr 24, http://www.kulturaihistoria.umcs.lublin.pl/archives/5031 (dostęp: 1.12.2016). 
— jest pochodzące z 1985 roku półamatorskie wydanie polskiego tłumaczenia powieści James Bond and Moonraker (1979) Christophera Wooda, która stanowiła literacką adaptację scenariusza do filmu Moonraker (reż. Lewis Gilbert, Wielka Brytania 1979). Co interesujące, w polskim tłumaczeniu utworu znalazły się dwa ważne błędy: po pierwsze, w tytule pojawiła się literówka (James Bond i Moonracker [sic!]); po drugie, na okładce nie występuje nazwisko Wooda — podana na niej informacja błędnie przypisuje autorstwo tekstu Ianowi Flemingowi ${ }^{51}$.

Strona formalna tej edycji każe zakwalifikować ją do tak zwanych wydawnictw klubowych. Świadczą o tym między innymi: ewidentnie amatorska warstwa typograficzna, graficzna i językowa publikacji, brak dbałości o detale edytorskie (przypisanie autorstwa Flemingowi, literówka w tytule, niepodanie nazwiska thumacza i osób biorących udział w procesie redakcyjnym), a także pojawiające się na stronie redakcyjnej oficjalne noty: „Do użytku wewnątrzorganizacyjnego” oraz „Nakład 100 egzemplarzy”. Tego rodzaju aktywność wydawnicza była jeszcze jedną praktyką typową dla okresu transformacji i procesu stopniowej emancypacji społecznej. Jak zauważa Zbigniew Wałaszewski, dziś trudno ocenić realny zasięg oddziaływania tak opublikowanej powieści (zwłaszcza że rzeczywisty nakład mógł być zdecydowanie wyższy od deklarowanego $)^{52}$, niemniej faktem pozostaje, że także w ten sposób Bond został wówczas wprowadzony do polskiej kultury.

Również około połowy dekady — we wrześniu 1986 - ukazał się monograficzny numer „Filmu na Świecie” (wydawanego przez Polską Federację Dyskusyjnych Klubów Filmowych) poświęcony Jamesowi Bondowi. Zasadniczą część zeszytu stanowił polski przekład fragmentów książki zachodnioniemieckiego krytyka Ericha Kociana Die James Bond Filme (München 1982). Partie udostępnione polskiemu czytelnikowi opisują historię postaci Bonda: wywód zaczyna się od literackich korzeni agenta, a następnie przybliża fakty dotyczące kolejnych produkcji, skupiając się przede wszystkim na ewolucji formy filmu bondowskiego, na wynikach finansowych oraz stylu gry poszczególnych aktorów wcielających się w rolę brytyjskiego szpiega. Cykl o Bondzie znajduje się tu zatem w centrum zainteresowania jako pewien wieloletni fenomen mający swoją historię i tradycję, która sama w sobie jest warta uwagi.

Oprócz fragmentów książki Kociana w numerze zawarto jeszcze wstęp Bronisława Pułaskiego (Ludowy bohater) i sporządzony przezeń spis filmów o Bondzie oraz esej Jamesa Bonda logika gry Jerzego Szyłaka. Teksty te ujawniają, w jaki sposób myślano o tych filmach w Polsce w latach 80 . i - co za tym idzie

${ }^{51}$ Powieść ta była 14. z kolei tekstem wydanym w ramach serii „Sensacja. Fantastyka”. Według katalogu Biblioteki Narodowej pojawiły się w tej serii jeszcze m.in. Złote wrota (The Golden Gate, 1976, pol. 1983) A. MacLeana i Akta Odessy (The Odessa File, 1972, pol. 1987) Fredericka Forsytha.

52 Z. Wałaszewski, Papierowy jednorożec, klubówka i „Łowca androidów”. O powstawaniu supersystemu rozrywkowego, [w:] Literatura i kultura popularna. Badania, analizy, interpretacje, [POPkultura - POPliteratura 4], red. A. Gemra, Wrocław 2015, s. 227. 
- po części wyjaśniają, dlaczego zdecydowano się na poświęcenie im numeru „Filmu na Świecie”. Obaj autorzy doceniają bowiem serię o Bondzie, wskazując na jej związki z szeroko pojętą tradycją i z autentycznymi ludzkimi potrzebami. Przewartościowanie w obrębie myślenia o kinematografii prowadzi Pułaskiego nie tyle nawet do akceptacji filmów o Bondzie, ile do uznania ich za wcielenie istoty kina:

Zacznę od tak zwanego prostego pytania — czym jest kino? Sztuką iluzji? Źródłem kompensacji? Rozrywką? Tak. Trzy razy tak. Właśnie tym jest kino. Od zarania dziejów dostarcza widzom zarówno rozrywki, jak wzruszeń. [...]

Nie wszystkie filmy, rzecz prosta, odpowiadają tym trzem kryteriom. Próżno szukać rozrywki u Bergmana, iluzji w cinéma-vérité. Te jednak, które spełniają wszystkie wymienione warunki, stanowią esencję kina. Można rzec — są bardziej filmowe od innych. Takie są właśnie filmy o przygodach superagenta 007, Jamesa Bonda ${ }^{53}$.

Podobne przewartościowanie, choć tym razem myślenia o kulturze w ogóle, miało wpływ na esej Szyłaka. Autor, wychodząc od tez Johana Huizingi o zabawie jako źródle kultury, interpretuje cykl o Bondzie właśnie w kategoriach gry, uznając, że rządzi ona zarówno relacjami wewnątrztekstowymi, jak i stosunkami między twórcami a odbiorcami:

Porównanie takie nie jest przypadkowe, bo naczelną zasadą filmów bondowskich jest gra, pojmowana nie tylko jako metafora określonych fabułą działań bohatera, lecz charakteryzująca również postępowanie twórców filmu i jego odbiorców ${ }^{54}$.

Bondowski numer „Filmu na Świecie” świadczy o kolejnym przesunięciu w dyskursie o agencie 007. Cykl o słynnym szpiegu staje się interesujący i warty opisania nie tylko ze względu na ogromną popularność, lecz także z uwagi na swoje właściwości. Tam, gdzie jeszcze w latach 60 . widziano tylko prymitywne epatowanie przemocą i seksualnością, teraz dostrzega się związki z pierwotnymi, nieusuwalnymi ludzkimi potrzebami lub sprawną realizację zadań kina jako takiego, a cały cykl okazuje się mieć swoją własną tradycję, w której istotną rolę odgrywa na przykład aktor grający Bonda i jego koncepcja tej postaci. Jest to zatem bardzo wyraźna zmiana w percepcji krytycznej całego cyklu — jej ślady można znaleźć również w kilku tekstach, które pojawiły się parę lat później, gdy część z filmów o Bondzie trafiła już do oficjalnej dystrybucji.

W 1988 i 1989 roku w prasie filmowej pojawiają się notatki i krótkie recenzje produkcji rozpowszechnianych już oficjalnie na wideo: Żyje się tylko dwa razy (You Only Live Twice, reż. Lewis Gilbert, Wielka Brytania 1967) ${ }^{55}$, Brylanty sq na zawsze (Diamenty sa wieczne - Diamonds Are Forever, reż. Guy Hamilton, Wielka Brytania 1971) $)^{56}$, Żyj i pozwól umrzeć (Live and Let Die, reż. Guy Hamil-

\footnotetext{
53 B. Pułaski, Ludowy bohater, „Film na Świecie” 1986, nr 333, s. 4.

54 J. Szyłak, Jamesa Bonda logika gry, „Film na Świecie” 1986, nr 333, s. 68.

55 Żyje się tylko dwa razy, „Filmowy Serwis Prasowy” 1988, nr 18.

${ }^{56}$ Brylanty sa na zawsze, „Filmowy Serwis Prasowy” 1988, nr 23/24.
} 
ton, Wielka Brytania 1973) ${ }^{57}$, Goldfinger oraz Człowiek ze ztotym pistoletem (The Man with the Golden Gun, reż. Guy Hamilton, Wielka Brytania 1974) ${ }^{58}$. W 1988 roku również do dystrybucji kinowej trafiło Żyj i pozwól umrzeć. W rok później zaś na wielki ekran wprowadzony zostaje Moonraker.

Choć wszystkie wymienione tytuły powstały przynajmniej dziesięć lat przed premierą w PRL-u, stosunek krytyków do nich nie był identyczny. W nieco inny sposób recenzenci podchodzą do Brylanty są na zawsze oraz Żyj i pozwól umrzé́ niż do Moonrakera. Jest to, jak zaznaczają sami autorzy, związane z przemianami estetyki filmu popularnego, wynikającymi z pojawienia się i ekspansji Kina Nowej Przygody.

Maciej Pawlicki rozpoczyna więc swoją recenzję Żyj i pozwól umrzeć znamiennymi słowami: „Sporo czasu minęło, nim pozwolono nam zobaczyć to, czym pasjonował się kinowy świat w czasach, kiedy Spielberg jeszcze koszulę w zębach nosił. Zobaczyć Bonda"59. I to właśnie Kino Nowej Przygody stanowi dla recenzenta punkt odniesienia do oceny produkcji, dlatego też krytyk podkreśla, że dla widza z końca lat 80. pierwszy film z Moore’em w roli Bonda będzie nudny i pełen dłużyzn - Pawlicki zaczyna swój wywód od przyznania się, iż zasnął na pierwszym seansie. Artykuł ten podkreśla, że przemiany estetyki kina popularnego sprawiły, iż Żyj i pozwól umrzeć stało się produkcją anachroniczną i straciło dawny powab:

Owa ujmująca grzeczność realizatorów, którzy lubią wszystko po dwa albo trzy razy powtórzyć, dotyczy także montażu i tempa opowiadania. Mające mrozić krew w żyłach pościgi i wszelkie przewracanki rozgrywają się w tempie raczej niemrawym, napięcie słabo jest napięte. Wiem, zgadzam się, że wszystko są to zarzuty kogoś, kto współżył już intensywnie z kinem Spielberga i jego satelitów. Wiem, ale nic na to nie poradzę. Kupiliśmy ten film o piętnaście, może - dwanaście lat za późno. [...] Przepraszam, ale nie mogę mieć szacunku dla staruszka, który przyszedł udawać hoże pacholę ${ }^{60}$.

Choć Żyj i pozwól umrzeć i Moonrakera oddzielało tylko kilka lat, to różnica formalna między obiema produkcjami jest zdecydowanie większa, gdyż drugi film zrealizowano już po spektakularnym sukcesie filmów spod znaku Kina Nowej Przygody. Kwestia ta została dostrzeżona również przez Jerzego Świtka, recenzenta „Filmu”, którego argumenty są niejako lustrzanym odbiciem przytaczanych opinii Pawlickiego. Świtek przywołuje bowiem cały szereg sądów i tez typowych dla krytycznych wypowiedzi o Kinie Nowej Przygody ${ }^{61}$. W tekście na temat Moonrakera zarzuca więc filmowi dominację aspektu wizualnego nad nar-

57 Żyj i pozwól umrzéc, „Filmowy Serwis Prasowy” 1988, nr 18.

58 Czlowiek ze złotym pistoletem, „Film” 1989, 1989, nr 18, s. 23; Goldfinger, „Film” 1989, nr 21, s. 23.

${ }_{59}$ M. Pawlicki, Śpij i pozwól zasnać, „Film” 1989, nr 18, s. 8.

${ }^{60}$ Ibidem, s. 9.

61 Szerzej na ten temat zob. E. Durys, Kino Nowej Przygody: postklasyczne Hollywood w polskiej krytyce filmowej, [w:] Polskie piśmiennictwo filmowe..., s. 223-224. 
racyjnym, niepotrzebne efekciarstwo, fabularną miałkość itd. Nowoczesna dynamika, której domagał się Pawlicki, dla Świtka jest już wadą:

Ale Moonrakera, uważanego za jeden ze słabszych odcinków cyklu, nie jest w stanie uratować nawet Moore, który tutaj ma mniejsze niż zwykle pole do popisu; twórcy bowiem największy nacisk położyli na dynamiczny przebieg akcji, gubiąc przy tym charakterystyczne cechy osobowości bohatera - jego błyskotliwość, inteligencję i dowcip ${ }^{62}$.

Analizowane teksty świadczą przede wszystkim o dwóch wyrazistych tendencjach, kształtujących w latach 80. polski dyskurs o Bondzie. Po pierwsze, seria o brytyjskim agencie (a zwłaszcza jej starsze części) ulega swoistemu uklasycznieniu, stając się swego rodzaju kanonem światowego kina (przynajmniej w jego wydaniu popularnym). Tego rodzaju kanon ma własną historię, tradycję i styl, których analizie można poświęcić monograficzny numer czasopisma i które stanowią punkt wyjścia do omawiania poszczególnych części cyklu. W ramach tego specyficznie konsekracyjnego stylu odbioru zaczyna się zwracać uwagę na takie cechy serii, jak autoironiczność i zdystansowanie względem własnej tradycji. W dyskursie poświęconym kulturze masowej dochodzi w ten sposób do swoistego przesunięcia — kodu krytycznego nie uruchamia się już do interpretowania cyklu bondowskiego, na horyzoncie wyłaniają się natomiast nowe zjawiska, które budzą zdecydowanie więcej kontrowersji. Istotne miejsce zajmowało tu między innymi kino akcji czy serial Niewolnica Isaura (Escrava Isaura, reż. Milton Gonçalves, Herval Rossano, sieć TV Rede Globo, Brazylia 1976-1977) — oszałamiająca popularność tych fenomenów wśród polskiej publiczności sprawiła, że rodzimi krytycy zaczęli im się przyglądać pilniej, formułując pod ich adresem dobrze znane zarzuty o prymitywne epatowanie przemocą (w przypadku pierwszym) ${ }^{63}$ i o bazowanie na tandetnych wzorcach sentymentalnych (w drugim) ${ }^{64}$. Zmieniła się więc nie tyle strategia retoryczna i sposób argumentacji, ile przedmiot, do którego zostały one zastosowane.

Po drugie, ważny punkt odniesienia dla ówczesnych odbiorców stanowiło Kino Nowej Przygody — krytycy mieli świadomość, że przyniosło ono rewolucję w estetyce filmu popularnego, choć różnie tę rewolucję oceniali. Pawlicki uznawał, iż nie da się odrzucić nowych przyzwyczajeń, dlatego też Żyj i pozwól umrzeć jawiło mu się jako produkcja anachroniczna i przestarzała. Z kolei Świtek, oceniając Moonrakera, uważał, że formuła Kina Nowej Przygody, którą w tym odcinku serii wykorzystano, przytłoczyła (wyobrażoną) istotę bondowskiego fenomenu. Te dwie - przeciwstawne w gruncie rzeczy - wypowiedzi dowodzą jednak, że krytycy mieli świadomość przekształceń, jakie dokonały się, właściwie na ich oczach, w estetyce kina popularnego, a stosunek do tych przekształceń

62 J. Świtek, Bond w kosmosie, „Film” 1989, nr 42, 10. Zob. też O. Sobański, Żywe światło dnia, „Film” 1989, nr 2, s. 11.

63 Zob. P. Wasiak, Filmy akcji...

${ }^{64}$ Zob. K. Stańczak-Wiślicz, O zwycięstwie „Niewolnicy Isaury” nad „Dyrektorami” kryzysowe debaty o kulturze popularnej w Polsce lat 80 . XX wieku, [w:] Kultura popularna w Polsce 1944-1989. Między projektem... 
wpływał również na nastawienie do bondowskiej serii. Dlatego Pawlicki skupia się na dramaturgii i sprawności inscenizacyjnej, natomiast Świtek uwypukla te cechy, które doprowadziły do konsekracji cyklu.

\section{Zakończenie}

Przedstawiona analiza wypowiedzi o fenomenie Jamesa Bonda stanowi w istocie próbę opisania historii przemian języków i narzędzi interpretacyjnych dostępnych rodzimym uczestnikom dyskursu okołofilmowego. W tym sensie owa próba może posłużyć nie tylko do zrozumienia funkcjonowania konkretnego cyklu literackiego i filmowego w Polsce Ludowej, lecz także do zarysowania ewolucji sposobów myślenia o kulturze popularnej w ogóle. Jednak, aby ten obraz zmiennych historycznie konceptualizacji i strategii pojmowania kultury masowej naszkicować w pełni, potrzebne są dalsze badania dotyczące zarówno polskiej recepcji konkretnych fenomenów, jak i wypowiedzi o charakterze teoretycznym i uogólniającym. W tym więc sensie niniejszy artykuł stanowi punkt wyjścia do szerszej analizy.

\section{Bibliografia}

\section{Opracowania}

Beksiński T., Boże, Bond to jest to, nie ma lepszego kina!, „Machina” 1996, nr 1.

Bodanko K., Eseje Marka Hłaski dla „Die Weltwoche”, „Zeszyty Literackie” 1990, nr 29.

Brylanty sq na zawsze, „Filmowy Serwis Prasowy” 1988, nr 23/24.

Cervoni A., James Bond — bohater naszych czasów?, „Film” 1965, nr 18.

Coctail z Jamesa Bonda, „Odgłosy” 1966, nr 35.

Człowiek ze złotym pistoletem, „Film” 1989, nr 29.

Durys E., Kino Nowej Przygody: postklasyczne Hollywood w polskiej krytyce filmowej, [w:] Polskie piśmiennictwo filmowe, red. P. Zwierzchowski, B. Giza, Wydawnictwo Uniwersytetu Kazimierza Wielkiego, Bydgoszcz 2013.

Eco U., Struktury narracyjne u Fleminga, [w:] Superman w literaturze masowej. Powieść popularna: między retoryka a ideologia, przeł. J. Ugniewska, Znak, Kraków 2008.

Fortuna G., jr, King Bruce Lee karate mistrz. Recepcja filmów sztuk walki w PRL-u, [w:] Poszukiwacze zaginionych znaczeń. Perspektywa (wy)twórcy, odbiorcy i krytyka w badaniach nad kulturq audiowizualnq, red. K. Łuczyńska, M. Stańczyk, Wydawnictwo Uniwersytetu Jagiellońskiego, Kraków 2016.

Fortuna G., jr, Wprowadzenie: szok transformacji, „Panoptikum” 2016, nr 15.

Głowiński M., Style odbioru. Szkice o komunikacji literackiej, Wydawnictwo Literackie, Kraków 1977.

Hłasko M., Od Ikara do Jamesa Bonda. Mit wyzwolonego człowieka, przeł., oprac. K. Bodanko, „Zeszyty Literackie” 1990, nr 30.

Klich-Kluczewska B., Młodzież, seks, cenzorzy i ludzie. Debata wokót filmu „Seksolatki”, [w:] Kultura popularna w Polsce 1944-1989. Między projektem ideologicznym a kontestacja, red. K. Stańczak-Wiślicz, Wydawnictwo Instytut Badań Literackich PAN, Warszawa 2015. 
Kornacki K., ,,Popiót i diament” Andrzeja Wajdy, słowo/obraz terytoria, Gdańsk 2011.

Kossak J., Stałe zagrożenie: kultura masowa, „Kultura” 1966, nr 34.

Krasucki E., Co towarzysz Wiestaw wiedziat o bigbicie? Świadomość zjawiska kultury masowej w okresie „popaździernikowym” (1956-1963), [w:] Kultura popularna w Polsce w latach 1944-1989. Problemy i perspektywy badawcze, red. K. Stańczak-Wiślicz, Fundacja Akademia Humanistyczna - Wydawnictwo Instytut Badań Literackich PAN, Warszawa 2012.

Krasucki E., Masowa kultura socjalistyczna. W poszukiwaniu definicji na przełomie lat pięćdziesiąych i sześćdziesiatych XX wieku, [w:] Popkomunizm. Doświadczenie komunizmu a kultura popularna, red. M. Bogusławska, Z. Grębecka, Libron, Kraków 2010.

KTT [Krzysztof Teodor Toeplitz], Kino grozy w domu, „Kultura” 1966, nr 32.

Lubelski T., Historia niebyła kina PRL, Wydawnictwo Znak, Kraków 2012.

M.D. [Mirosław Derecki], W sidłach agenta 007, „Kamena” 1969, nr 9.

M.D., Z frontu Bondomanii, „Film” 1966, nr 37.

Macdonald D., Teoria kultury masowej, przeł. C. Miłosz, [w:] Kultura masowa, wyb., przeł., przedm. C. Miłosz, kom. J. Szacki, Wydawnictwo Literackie, Kraków 2002.

mol, James Bond i kultura masowa, „Film” 1973, nr 8.

Najpopularniejszy bohater filmowy, „Kino” 1966, nr 1.

Pawlicki M., Śpij i pozwól zasnać, „Film” 1989, nr 18.

Pilot M., Agent 007, „,Tygodnik Kulturalny” 1969, nr 20.

Polskie piśmiennictwo filmowe, red. P. Zwierzchowski, B. Giza, Wydawnictwo Uniwersytetu Kazimierza Wielkiego, Bydgoszcz 2013.

Przyczynek do ,, bondologii”, „Kultura” 1966, nr 13.

Pułaski B., Ludowy bohater, „Film na Świecie” 1986, nr 333.

Sierecki S., W magicznym kregu Jamesa Bonda, „Litery” 1967, nr 3.

Skwara J., Film zachodni a polityka, Wydawnictwo Ministerstwa Obrony Narodowej, Warszawa 1970.

Sław, Komu - i czemu — stuży James Bond, „Trybuna Ludu” 26 X 1965.

Staiger J., W stronę historyczno-materialistycznych badań nad recepcja filmu, przeł. I. Kurz, [w:] Film i historia. Antologia, red. I. Kurz, Wydawnictwo Uniwersytetu Warszawskiego, Warszawa 2008.

Stańczak-Wiślicz K., O zwycięstwie „Niewolnicy Isaury” nad „Dyrektorami”— kryzysowe debaty o kulturze popularnej w Polsce lat 80. XX wieku, [w:] Kultura popularna w Polsce 1944-1989. Między projektem ideologicznym a kontestacja, red. K. Stańczak-Wiślicz, Wydawnictwo Instytut Badań Literackich PAN, Warszawa 2015.

Strinati D., Wprowadzenie do kultury popularnej, przeł. W.J. Burszta, Zysk i S-ka, Poznań 1998.

Szyłak J., Jamesa Bonda logika gry, „Film na Świecie” 1986, nr 333.

Świtek J., Bond w kosmosie, „Film” 1989, nr 42.

Talarczyk-Gubała M., Poszukiwana, poszukiwany... Krytyka wobec polskiej komedii filmowej lat 1945-1989, [w:] Polskie kino popularne, red. P. Zwierzchowski, D. Mazur, Wydawnictwo Uniwersytetu Kazimierza Wielkiego, Bydgoszcz 2011.

Toeplitz K.T., Przyczynek do 007 bondologii, „Kultura” 1965, nr 52.

Tracz B., „Zdemoralizowane brudasy”. Początki ruchu hipisowskiego w Polsce oraz przeciwdziatania ze strony instytucji wychowawczych i represyjnych państwa, [w:] Od kontrkultury do New Age. Wybrane zjawiska spoteczno-kulturowe schytku PRL i ich korzenie, red. E. Chabros, Oddział Instytutu Pamięci Narodowej — Komisja Ścigania Zbrodni przeciwko Narodowi Polskiemu, Wrocław 2014.

Turowska M., ,, Bohater” naszych czasów, „Kultura Filmowa” 1968, nr 3.

Wałaszewski Z., Papierowy jednorożec, klubówka i „Łowca androidów”. O powstawaniu supersystemu rozrywkowego, [w:] Literatura i kultura popularna. Badania, analizy, interpretacje, red. A. Gemra, Pracownia Literatura i Kultury Popularnej oraz Nowych Mediów Uniwersytetu Wrocławskiego, Wrocław 2015.

Literatura i Kultura Popularna 24, 2018

(C) for this edition by CNS 
Wasiak P., Filmy akcji, magnetowidy i autorytet krytyków kulturalnych, [w:] Kultura popularna w Polsce 1944-1989. Między projektem ideologicznym a kontestacja, red. K. Stańczak-Wiślicz, Wydawnictwo Instytut Badań Literackich PAN, Warszawa 2015.

Wierzchowska A., Literacka subkultura? Polski fandom w latach osiemdziesiatych, [w:] Społeczeństwo polskie w latach 1980-1989, red. N. Jarska, J. Olaszek, Instytut Pamięci Narodowej Komisja Ścigania Zbrodni przeciwko Narodowi Polskiemu, Warszawa 2015.

Wyżyński A., Niezrealizowane pomysty filmowe Stanisława Barei, [w:] Kino, którego nie ma, red. P. Zwierzchowski, D. Wierski, Wydawnictwo Uniwersytetu Kazimierza Wielkiego, Bydgoszcz 2013.

Z.P. [Zbigniew Pitera], Ognista kula, „Film” 1966, nr 4.

Zwierzchowski P., Pęknięty monolit. Konteksty polskiego kina socrealistycznego, Wydawnictwo Uniwersytetu Kazimierza Wielkiego, Bydgoszcz 2005.

Zwierzchowski P., Kornacki K., Metodologiczne problemy badania kina PRL-u, „Kwartalnik Filmowy" 2014, nr 85.

Żyj i pozwól umrzeć, „Filmowy Serwis Prasowy” 1988, nr 18.

Żyje się tylko dwa razy, „Filmowy Serwis Prasowy” 1988, nr 18.

\title{
Źródła internetowe
}

Siuda P., Elita popkulturowego dostęu. Fanowski odbiór popkultury w Polskiej Rzeczypospolitej Ludowej jako sprzeciw wobec systemu politycznego — przyktad fandomu science-fiction, „Kultura i Historia” 2013, nr 24, http://www.kulturaihistoria.umcs.lublin.pl/archives/5031.

Wasiak P., „Zwoje muskutów monstrualnych rozmiarów i dużo nagiego ciała”. Kultura popularna, nowe technologie medialne i legitymizacja socjalistycznego projektu kulturowego, „Kultura Popularna" 2014, $\mathrm{nr} 40$, https://kulturapopularna-online.pl/resources/html/article/details?id=12283.

\section{Agent 007 behind the Iron Curtain: The phenomenon of James Bond in the cultural writings of the Polish People's Republic}

\author{
Summary
}

The topic of the article is the reception of the phenomenon of James Bond in cultural writings from the times of the Polish People's Republic. Though an average member of the Polish audience could not be directly familiar with the character (neither in literature nor in film), the scale of the popularity of the brand in the West meant that the echoes of the so-called Bondomania started to reach countries behind the Iron Curtain. Polish critics and journalists tried to acquaint their readers with the issue and explain it using various interpretative categories.

The article attempts to reconstruct these categories and their hierarchy of values. Based on theses formulated by Janet Staiger (Interpreting Films: Studies in the Historical Reception of American Cinema), the author analyses the changes to Polish interpretations and opinions on the Bond phenomenon in subsequent decades and indicates the historical conditions that influenced those changes. The text focuses primarily on two periods: 1964-1971 and the latter half of the 1980s, because it was in those times that the interest of Polish critics in James Bond was particularly strong. 